\title{
Research on the Effect of an Environmental Protection Tax Policy on Haze Control in China-Empirical Analysis Based on Provincial Panel Data
}

\author{
$\mathrm{Xia} \mathrm{Li}^{1, *}$ and Guangyao Deng ${ }^{2}$ \\ 1 School of Economics and Management, Shanghai University of Political Science and Law, \\ Shanghai 201701, China \\ 2 School of Statistics, Lanzhou University of Finance and Economics, Lanzhou 730020, China; \\ dgy316203@163.com \\ * Correspondence: lixia@shupl.edu.cn
}

Citation: Li, X.; Deng, G. Research on the Effect of an Environmental Protection Tax Policy on Haze Control in China-Empirical Analysis Based on Provincial Panel Data. Sustainability 2022, 14, 41. https://doi.org/10.3390/su14010041 Academic Editors: Baojie He, Ayyoob Sharifi, Chi Feng and Jun Yang

Received: 2 November 2021 Accepted: 13 December 2021 Published: 21 December 2021

Publisher's Note: MDPI stays neutral with regard to jurisdictional claims in published maps and institutional affiliations.

Copyright: (C) 2021 by the authors. Licensee MDPI, Basel, Switzerland. This article is an open access article distributed under the terms and conditions of the Creative Commons Attribution (CC BY) license (https:// creativecommons.org/licenses/by/ $4.0 /)$.

\begin{abstract}
This paper describes the construction of a model to explore the effectiveness of environmental protection taxes on haze emission reduction in China. The model is based on panel data from 30 provinces and cities in China, from 2003-2019. It is found that the current environmental protection tax has a significant inhibitory effect on haze. In addition, an upfront pollutant discharge fee can guide enterprises to significantly reduce the emission of haze-causing pollutants. A robustness test is conducted, using the variable substitution method of taking sulfur dioxide $\left(\mathrm{SO}_{2}\right)$ as haze, and the research conclusions are consistent. We then put forward three specific suggestions: (1) Expand the scope of the environmental protection tax, gradually increase the tax rate, or adopt an excessive progressive tax rate. For example, China could consider including mobile pollution sources into the scope of taxation. (2) Increase the supervision and collection of the environmental protection tax. (3) Strengthen the multiple linkages between regional taxation departments and environmental protection departments, in order to form a collaboration between the departments in an effort to control haze and promote the sustainable development of the Chinese economy and the environment.
\end{abstract}

Keywords: environmental protection tax; pollutant discharge fee; haze; emission reduction effect; PM2.5

\section{Introduction}

Since the founding of New China, especially since the reform and opening up, our country's economy has taken off rapidly. However, while China has experienced great development and made brilliant achievements, it has also caused environmental pollution problems and placed great pressure on the ecological environment. In the autumn and winter seasons each year, most cities in China enter a time when "haze on all sides" occurs frequently. In particular, the normalization of various degrees of haze in industrial cities throughout the year is a continuous warning people of the seriousness of China's air pollution problem. For example, in January 2013, four haze processes covered 30 provinces (regions and cities) across the country. In Beijing, only five days in the entire month were not hazy days. On 4 January 2013, the Asian Development Bank and Tsinghua University jointly released the "National Environmental Analysis of the People's Republic of China" report. The document showed that less than $1 \%$ of China's 500 largest cities have air quality that meets the World Health Organization standards. In addition, seven of the ten most serious cities in the world in terms of air pollution are in China. In recent years, China has been plagued by severe PM2.5 pollution [1]. When examining the history of economic development and environmental protection in developed countries, one can see that those countries have gone through hundreds of years of industrialization. For example, London has been called "Fog City" because of the years of serious environmental pollution, which were followed by years of environmental management. China's air pollution problem has not only seriously affected the country's sustained economic growth and social harmony, 
but has also threatened people's living environment and health. We must learn and implement $\mathrm{Xi}$ Jinping's scientific assertion that "clear waters and green mountains are as valuable as gold and silver mountains". China must manage environmental pollution and adhere to sustainable development strategies.

The report of the Eighteenth National Congress of the Communist Party of China pointed out that efforts should be made to strengthen the construction of ecological civilization. Environmental pollution control should be taken as a key direction for the construction of ecological civilization, and a beautiful China should be built. The report of the 19th National Congress of the Communist Party of China also pointed out that insisting on the "harmonious coexistence between man and nature" has become one of the fourteen strategies to which the green economy should adhere. Efforts should be made to develop socialism with Chinese characteristics. The most significant form of pollution in the environmental pollution problem is air pollution. In order to prevent and control air pollution, China needs to win the battle to defend the blue sky. To win this blue-sky defense war, the first thing that must be overcome is haze. Controlling smog and improving air quality are the only ways; these are the problems that must be faced and overcome to develop a low-carbon economy and achieve sustainable development.

On 5 March 2014, Premier Li Keqiang delivered a government work report at the Second Session of the Twelfth National People's Congress. The report stated that China has strengthened environmental tax legislation, adopted a series of measures to combat environmental pollution, and made the unprecedented announcement, "We must resolutely declare war on pollution as we declare war on poverty." At present, according to the principle of "tax and fee shift", China has changed the pollution discharge fee to an environmental protection tax. The effect of this tax policy on haze governance and how to improve and optimize the fiscal and taxation policies of haze prevention and control in China are issues very worthy of study. This study proposes ideas and suggestions for fiscal policy reform based on the in-depth discussion of the current implementation status of China's fiscal policy. In addition, an empirical analysis of fiscal policy effects of haze management and the experience of foreign fiscal policy on haze prevention and control are considered. These are all of theoretical significance and important practical value for China's current development of a low-carbon economy. If implemented, this study's suggestions would strengthen the construction of China's green economy and ecological civilization, help manage haze, improve the environment, and promote the sustainable development of China's economy and environment. This research has certain theoretical significance and important practical value in the following aspects: the development of a low-carbon economy, strengthening the construction of a green economy and ecological civilization, controlling haze levels, improving the environment, and promoting the sustainable development of China's economy and environment.

\section{Brief Literature Review and Theoretical Analysis}

\subsection{Brief Literature Review}

In accordance with the principle of "tax burden shift", China changed the pollution discharge fee to an environmental protection tax. The environmental protection tax was introduced on 1 January 2018, and the implementation time was relatively short. Regarding the available research, because of the short implementation period of the environmental protection tax, the only data that can be obtained as of now are for 2018 and 2019. Therefore, the existing research mainly involves the exploration of four aspects. The first aspect is the levy of environmental taxes; on this issue, various experts have different opinions. In some European countries, the environmental effects of environmental protection taxes have been widely recognized [2]. Many countries have adopted economic means, such as carbon taxes, to promote the reduction of greenhouse gases such as carbon dioxide [3]. From a policy perspective, taxation policies and systems can reduce the harm caused by sulfur dioxide to air quality [4]. Jia Kang [5] argued that attention must be paid to the control of smog. The study examined whether China could independently issue new taxes, called 
"carbon taxes" or "sulfur taxes" by Western countries. Wu Xuean [6] reported that the introduction of environmental taxes is not a panacea for smog control, because polluting companies will pass the tax burden on to consumers. The study argued that such taxes will not help the control of haze, but will, in fact, also cause corporate pollution. The second aspect is that many studies have argued that a pollutant discharge fee system can also guide enterprises to reduce environmental pollution. The studies of Magat et al. [7] and Laplante et al. [8] showed how the implementation of environmental economic measures could effectively reduce the level of pollution emissions. Wang and Wheeler [9] used corporate data to explore the emission reduction effects of China's pollution discharge fee system. The study found that emissions fees can force companies to significantly reduce emissions. Pollutant discharge fees can also be used to control the total emissions of air pollutants through air pollutant emission rights trading [10]. In view of the haze caused by the dust generated in the urbanization construction process, the pollution discharge fee collection standard should be increased to reduce the occurrence of hazy weather [11]. The third aspect is that existing research has focused on the institutional effects of the pollutant discharge fee on the environment $[12,13]$. Regional heterogeneity exists in the emission reduction effects of environmental protection taxes. Some studies believe that, among taxes in China, the urban construction tax has a better emission reduction effect; the emission reduction effects of other environmental protection taxes and fees are not obvious [14]. There are also opposing views, namely that the environmental protection tax can reduce wastewater and waste gas emissions, but the reduction of solid waste emissions is not obvious [15]. Some experts have used simulation methods in their studies. For example, the CGE model has been used to analyze the existence of policy effects of lowering personal and corporate income taxes by imposing environmental taxes at the regional level [16]. The fourth aspect is the system design of environmental protection tax. This involves the design of reasonable tax rates in certain areas, supplemented by the provision of reasonable subsidies and tax incentives. These rates and subsidies will promote the technological innovation of enterprises, specifically with regard to reducing pollution and improving emissions reduction [17]. Some experts have performed in-depth research on the scope and tax rate of environmental protection tax: Pászto et al., (2020) found that in 2017, the governments of some Central and Eastern European countries, such as Slovenia, Croatia, and Hungary, actively levied environmental taxes, and that their income from environmental taxes was relatively high. Some EU member states are implementing national and even local environmental taxes, mainly concentrated in areas such as transportation tax, resource tax, pollution tax, and product tax. However, the overall environmental tax rate for transportation vehicles is low, or sometimes not. It is recommended that environmental taxes increase the tax rate and increase the collection of traffic pollution [18]. López Pérez et al., (2021) found that since 2014, Mexico has levied environmental taxes in a small range and extremely low carbon emission prices, resulting in less income from environmental taxes. In order to improve the environment and increase environmental tax revenue, it should be necessary to significantly expand the scope of environmental tax collection and accelerate the increase of environmental tax rates [19]. Hu et al., (2020) collected data on more than 100,000 sewerage charges and sewerage charges from 4300 sewage companies in Yunnan Province, China in 2017. The study found that the coverage of environmental protection taxes in 2018 was narrow and agricultural pollutants were not included. The environmental protection tax rate was notably low, and was not enough to encourage enterprises to reduce pollution. It was recommended that the government gradually increase the tax rate of environmental protection tax, and at the same time increase the compensation for environmental protection activities of enterprises to encourage green development of enterprises [20]. Chien et al., (2021) showed that environmental taxes had a positive impact on the environment of Asian countries [21].

The abovementioned documents mainly involve pollution discharge fees, carbon taxes, sulfur taxes, and related tax policies' emission reduction effects on the environment, as well as suggestions on tax reforms, such as the scope and tax rate of environmental protection 
taxes in European Union, Mexico, and China. Experts have made significant contributions in these areas. However, there are certain shortcomings in the emission reduction effect of the pollution discharge fee after the environmental protection tax and the selection of haze indicators. This paper uses empirical analysis of the provincial panel data for 30 provinces and cities from 2003 to 2019; the original data for haze indication comes from the atmospheric composition analysis team of Dalhousie University, which uses NASA satellites and data from ground monitoring stations. These date are used to perform an empirical analysis of the pollution reduction effect after pollution taxes and environmental protection taxes. It is conducive to making suggestions for the further improvement of the relevant taxation system, and better promoting the harmonious coexistence of man and nature.

\subsection{Theoretical Analysis}

Due to the negative externalities in the discharge of pollutant emissions, taxation on negative externalities is an effective means to solve the market failure. Moreover, an environmental protection tax increases the marginal emission cost of enterprises by internalizing the external costs generated in the production process, so as to achieve pollution reduction [22]. The environmental protection tax can be traced back to the Pigou tax, which was initially proposed by the welfare economist Pigou. The Pigou tax is a taxation method of levying taxes on environmentally polluting enterprises; the tax's mechanism is to internalize the externality of enterprises. The Pigou tax and the Coase Theorem are complementary to each other to some extent. The Pigou tax pays more attention to fairness; whoever pollutes, pays the tax. The Coase Theorem pays more attention to efficiency, focusing on the maximization of overall benefits (DeSerpa, 1994) [23]. The application of the Coase Theorem is very limited. It requires many restrictive assumptions, including that the transaction cost is zero (Deryugina et al., 2021) [24]; in reality, it is difficult for the transaction cost to be zero. Both parties also need relevant government departments to clarify the property rights.

At the same time, the relevant theories in this paper can be traced back to the externality theory and the Coase theorem. These two theories can be used to understand how and why the environmental protection tax is a tax levied on enterprises that damage the environment. The aim of the tax is to make the private cost of the enterprise equal to the social cost, and the private interest should be equal to the social interest. These taxes can also be used to internalize the externalities by merging enterprises, as well as to solve the problem of external diseconomies by clarifying property rights and working through the market.

The environmental protection tax discussed in this article was implemented on 1 January 2018. The environmental protection tax is calculated based on the amount of emissions such as air pollution, water pollution, solid waste, noise, and multiplied by the applicable tax amount. Environmental protection taxes are levied by tax authorities above the county level where pollutants are discharged. Because local governments have assumed the main responsibilities of pollution control and environmental protection, the state has fully mobilized local enthusiasm and improved the local tax system. Environmental protection taxes are considered local taxes, and the relevant environmental protection tax revenues belong to local governments; local governments also use their revenues to reduce the investment and expenditure of pollution control and environmental protection.

The theoretical analysis of the path of environmental protection tax on smog in this article is as follows: If an environmental protection tax is imposed on a company, the company's production cost will increase. Based on Pigou's tax and the Coase theorem, external costs will be internalized, which will increase the marginal production cost of the company's products and force the company to reduce emission of pollutants. From another perspective, the more the environmental protection tax is levied, the more it will promote enterprises to update environmental protection equipment and reduce the emission of pollutants. The pollutants of sulfur dioxide, nitrogen oxides, and inhalable particulate matter are also the main components of smog. In part, the collection of environmental protection tax and then environmental protection tax will reduce smog. In general, the levy 
of environmental protection taxes will restrict the emission of pollutants by enterprises, and will also restrain the emission of smog, which can have a reduction effect on smog.

The above points constitute the theoretical hypothesis of this empirical study.

\section{Research Design}

\subsection{Variable Description and Measurement Index of Empirical Model}

This article collects and examines data from 30 provinces in China, from 2003 to 2019, by consulting the official website of the National Bureau of Statistics, "China Statistical Yearbook", "China Tax Yearbook", "China Environment Yearbook", and "China Environment Statistics Yearbook", as well as various provincial statistical yearbooks (Tibet is excluded due to missing data). Specifically investigated are the environmental protection taxes (fees) of autonomous regions and municipalities directly under the central government control, completed investment in industrial waste gas treatment, regional GDP, foreign direct investment, proportion of secondary industries, and population at the end of each year. The original data for the annual average concentration of fine particulate matter (PM2.5) in the 30 provinces and cities originated from the Atmospheric Composition Analysis Group of Dalhousie University (Atmospheric Composition Analysis Group). This group uses NASA satellites and ground monitoring stations to obtain average PM2.5 concentrations in a year.

\subsection{Research Hypothesis}

Theoretically, the emission reduction effect of environmental protection taxes and emission fees is consistent with the taxation principle of the Pegu tax. The principle is to induce the internalization of enterprises' external costs, which, in turn, will reduce the production of these enterprises' polluting products. Thus, the tax will have an impact on the annual average concentration of PM2.5 and promote the reduction of pollutant emissions by enterprises. Therefore, the following hypothesis is proposed: Increasing the environmental protection tax will reduce the annual average concentration of PM2.5 in provinces and cities, which is beneficial to emissions reduction.

\subsection{Variable Selection}

\subsubsection{The Explained Variable}

The core explanatory variable of this paper is the annual average concentration of PM2.5, from 2003 to 2019, in 30 provinces, cities, and municipalities directly under control of the central government. It is known that PM2.5 is a constituent of the earth's atmosphere. Although the quantity of PM2.5 in the atmosphere is small, it plays an important role in the study of air quality and pollutant emissions. In addition, PM2.5 can be used to explain indicators such as emission reduction and pollutant gas emissions. This is because the causes of PM2.5 exceeding the standard are mainly the burning of various fossil energy sources, automobile exhaust emissions, industrial manufacturing and so on. This article does not choose exhaust gas, wastewater, and waste as the explanatory variables. This is because the emissions of the three wastes themselves have a two-way causal relationship with the emission charges, which leads to the endogenous nature of the emission charges. Therefore, the annual average concentrations of PM2.5 were chosen to precisely overcome this problem. In particular, the raw data (2003-2018) of annual average PM2.5 concentrations for 30 provinces and cities were sourced from the Atmospheric Composition Analysis Group (ACAG) of Dalhousie University. This group uses NASA satellites, as well as data from ground-based monitoring stations, to obtain annual average PM2.5 concentrations over a year. The data in 2019 are not yet updated on this website, so in this study, the data in 2019 are derived from the average of the years 2003-2018.

\subsubsection{Explanatory Variables}

China legislated and implemented the environmental protection tax, which basically follows the standard of the pollutant discharge fee that was levied before 2018, and which complemented the environmental protection tax to some extent. Therefore, the data before 
2018 can be used as explanatory variables by using the pollutant discharge fee. The original data were obtained from the China Environment Yearbook and China Taxation Yearbook.

\subsubsection{Control Variables}

In addition to the explanatory variables and explanatory variables, control variables should also be added to the established model.

1. Completed investment in industrial waste gas treatment

The company's investment in industrial waste gas treatment (IWG) (2003-2019) is selected as one of the control variables. The original data come from the "China Environmental Statistics Yearbook" (2004-2020). Theoretically speaking, increasing the investment and governance of industrial waste gas will promote technological progress and have a good impact on the emissions reduction effect. However, whether excessive investment will lead to a waste of resources and lead to poor development of emissions reduction depends on the following data analysis.

\section{Regional GDP}

We have collected the GDP of each province during the study years. Usually, the lower the GDP of a region, the more backward the region's economy. In such cases, more importance is placed on economic development and less importance is placed on environmental pollution. Further, more energy resources are used to drive heavy economic development, which also aggravates the annual average concentration of PM2.5 and has a negative impact on the emissions reduction effect.

\section{Industrial structure}

We use the share of the secondary industry in the sum of primary, secondary, and tertiary industries in each province and city as the industrial share (Ip) of that province. On the one hand, the higher the share of secondary industry in a province or city is, the more developed is the province's or city's industry. On the other hand, the higher share of secondary industry also indicates that more resources are consumed by the secondary industry's industrial development. In this case, more waste gas, wastewater, and other wastes are emitted, and the pollution of the atmosphere and the negative impact on the emissions reduction effect are more serious.

\section{Degree of external openness}

In this paper, the logarithm of foreign direct investment (lnFdi) is used to represent the degree of openness to the outside world. Generally speaking, the greater the degree of openness of a province or city to the outside world is, that is, the more foreign direct investment, there will be relatively more industry and a greater the impact on environmental pollution.

In order to partially eliminate the heteroskedasticity of the non-stationary time series and to reduce the bias of the regression results, the natural logarithm of all variables is taken in this paper. This can also more intuitively reflect the elasticity of the explanatory variables.

\section{Year-end population}

In this paper, we collected the population (the number of people) of each province at the end of each calendar year. Generally speaking, the larger the population is, the more resources and energy are consumed, and the more various pollutants are produced. A larger population will increase the impact on the environment and cause pollution to the air. The larger the population, the more negative the impact on the emissions reduction effect.

The specific descriptive statistics of each variable are shown in Table 1. 
Table 1. Descriptive statistics of main variables.

\begin{tabular}{|c|c|c|c|c|c|}
\hline Variable & Definition & Mean & $\begin{array}{l}\text { Standard } \\
\text { Deviation }\end{array}$ & Minimum & Maximum \\
\hline PM2.5 & $\begin{array}{l}\text { PM2.5 value of each province } \\
\text { and city }\end{array}$ & 39.27 & 16.05 & 9.006 & 83.61 \\
\hline Eptax & Environmental protection tax & 55,890 & 50,309 & 865.8 & 358,888 \\
\hline IWG & $\begin{array}{l}\text { Investment in the treatment of } \\
\text { industrial waste gas by } \\
\text { provinces and cities }\end{array}$ & 114,399 & 141,441 & 140 & $1,300,000$ \\
\hline GDP & Regional GDP & 17,274 & 17,180 & 390.2 & 107,671 \\
\hline People & $\begin{array}{c}\text { Population of each province at } \\
\text { the end of each year }\end{array}$ & 4444 & 2686 & 61.35 & 11,521 \\
\hline Ip & $\begin{array}{l}\text { Proportion of the secondary } \\
\text { industry in the total of the } \\
\text { primary, secondary and } \\
\text { tertiary industries }\end{array}$ & 45.73 & 8.339 & 16.20 & 61.50 \\
\hline Fdi & Degree of external openness & 624,943 & 708,551 & 476.9 & $3,576,000$ \\
\hline
\end{tabular}

Note: The observed values of descriptive statistical variables are all 510.

A line graph of environmental protection taxes for 30 provinces and municipalities (autonomous regions) for all years was made using Stata 15.1, as shown in Figure 1.

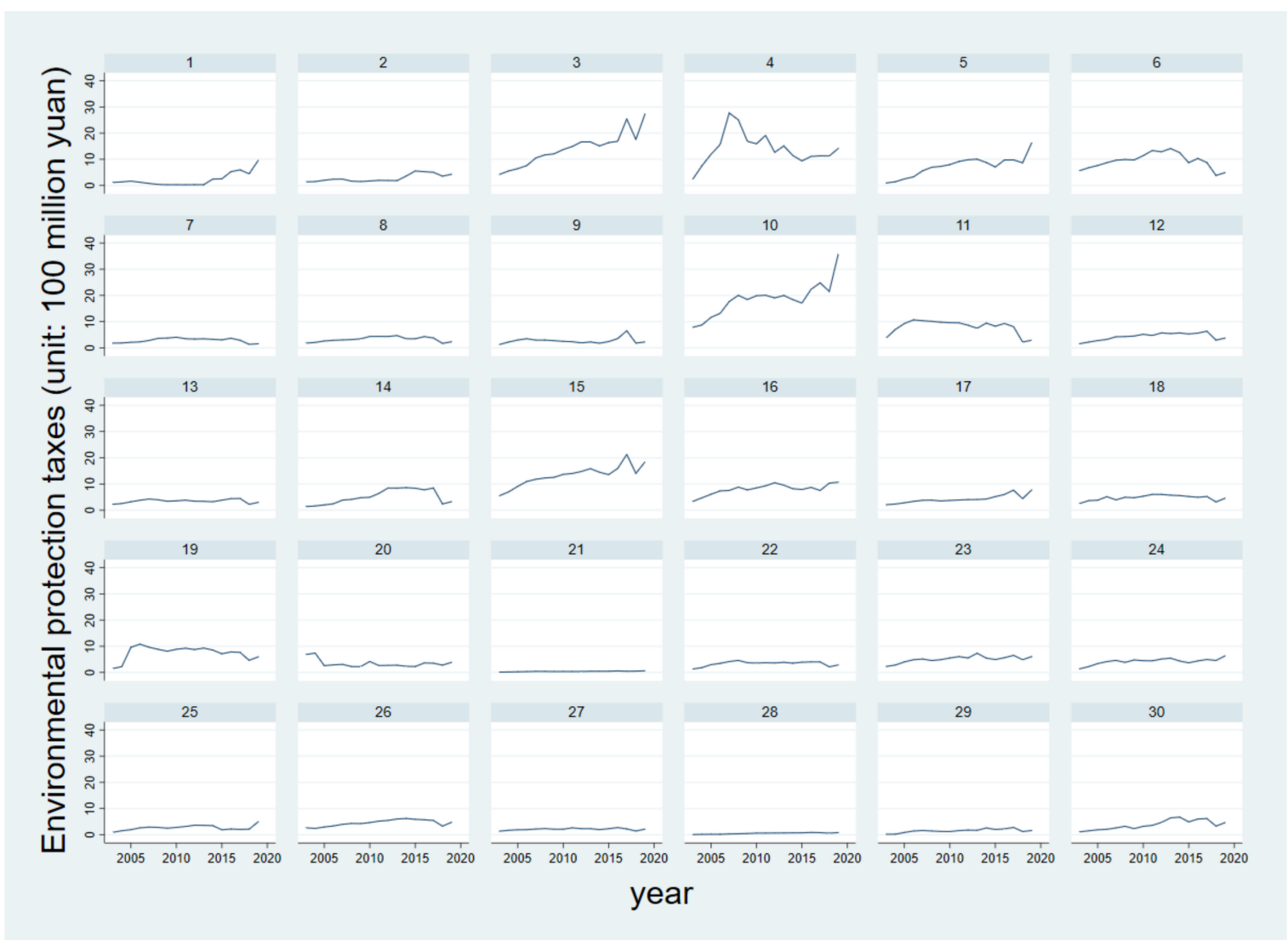

Figure 1. Environmental protection taxes of 30 provinces and cities (autonomous regions), from 2003 to 2019 (unit: 100 million yuan). Data sources: "China Environmental Yearbook", "China Environmental Statistical Yearbook" and "China Statistical Yearbook". The numbers 1-30 in Figure 1, respectively, represent Beijing, Tianjin, Hebei, Shanxi, Inner Mongolia, Liaoning, Jilin, Heilongjiang, Shanghai, Jiangsu, Zhejiang, Anhui, Fujian, Jiangxi Province, Shandong Province, Henan Province, Hubei Province, Hunan Province, Guangdong Province, Guangxi Zhuang Autonomous Region, Hainan Province, Chongqing City, Sichuan Province, Guizhou Province, Yunnan Province, Shaanxi Province, Gansu Province, Qinghai Province, Ningxia Hui Autonomous Region, and Xinjiang Uygur Autonomous Region. 


\subsection{Setting of the Measurement Model}

The baseline model of the research hypothesis is set as follows:

$$
\operatorname{lnPM} 2.5_{i, \mathrm{t}}=\beta_{0}+\beta_{1} \operatorname{lnEptax}_{i, t}+\beta_{2} \operatorname{lnIwg}_{i, t}+\beta_{3} \operatorname{lnGDP}_{i, t}+\beta_{4} \ln \mathrm{Fdi}_{i, t}+\beta_{5} \operatorname{lnIp}_{i, t}+\beta_{6} \ln \text { People }_{i, t}+\varepsilon_{i, t}
$$

In the above model, $i$ and $t$ identify the province dimension and time dimension, respectively. The explanatory variables in the model are as follows: $\ln P M 2.5$ represents the logarithm of the average concentration of PM2.5 in each province. The core explanatory variable $\operatorname{lnEptax}$ corresponds to the provincial environmental protection tax. Others are control variables. Among them, lnIwg denotes the logarithm of the investment in the treatment of industrial waste gas in each province; lnPeople represents the logarithm of the population of each province at the end of the year; lnGDP represents the logarithm of the province's GDP; and lnIp represents the second place in each province. The logarithm of the proportion of the industrial output value is the total output value of the primary, secondary, and tertiary industries. Finally, lnFdi represents the logarithm of the foreign direct investment of each province and represents the random disturbance term of the model.

\subsection{Empirical Results and Analysis}

This paper adopts the ordinary least squares (OLS) method based on the benchmark regression and uses the two-way fixed effect of regional time. The regression results of the impact of environmental protection tax on smog (as given in Table 2) are as discussed below.

Table 2. The effect of environmental protection taxes on haze reduction.

\begin{tabular}{|c|c|c|c|c|c|c|}
\hline LnPM2.5 & Model 1 & Model 2 & Model 3 & Model 4 & Model 5 & Model 6 \\
\hline lnEptax & $\begin{array}{c}-0.159^{* * *} \\
(0.012)\end{array}$ & $\begin{array}{c}-0.125^{* * *} \\
(0.033)\end{array}$ & $\begin{array}{c}-0.087^{* * *} \\
(0.020)\end{array}$ & $\begin{array}{c}-0.084^{* * *} \\
(0.019)\end{array}$ & $\begin{array}{c}-0.070 * * * \\
(0.019)\end{array}$ & $\begin{array}{c}-0.070 * * * \\
(0.019)\end{array}$ \\
\hline $\operatorname{lnIwg}$ & & $\begin{array}{c}-0.042 * * * \\
(0.016)\end{array}$ & $\begin{array}{c}-0.026^{* *} \\
(0.011)\end{array}$ & $\begin{array}{c}-0.024 \text { ** } \\
(0.010)\end{array}$ & $\begin{array}{c}-0.022 \text { ** } \\
(0.010)\end{array}$ & $\begin{array}{c}-0.022 \text { ** } \\
(0.010)\end{array}$ \\
\hline $\operatorname{lnGDP}$ & & & $\begin{array}{c}-0.093^{* * *} \\
(0.016)\end{array}$ & $\begin{array}{c}-0.142^{* * *} \\
(0.020)\end{array}$ & $\begin{array}{c}-0.112 * * * \\
(0.021)\end{array}$ & $\begin{array}{c}-0.114^{* * *} \\
(0.021)\end{array}$ \\
\hline $\operatorname{lnFdi}$ & & & & $\begin{array}{c}0.061^{* * *} \\
(0.014)\end{array}$ & $\begin{array}{c}0.051^{* * *} \\
(0.014)\end{array}$ & $\begin{array}{c}0.051^{* * *} \\
(0.014)\end{array}$ \\
\hline $\operatorname{lnIp}$ & & & & & $\begin{array}{c}0.280^{* * *} \\
(0.070)\end{array}$ & $\begin{array}{c}0.281^{* * *} \\
(0.070)\end{array}$ \\
\hline lnPeople & & & & & & $\begin{array}{c}0.023 \\
(0.033)\end{array}$ \\
\hline _cons & $\begin{array}{c}3.133^{* * *} \\
(0.187)\end{array}$ & $\begin{array}{c}1.860^{* * *} \\
(0.134)\end{array}$ & $\begin{array}{c}2.843^{* * *} \\
(0.313)\end{array}$ & $\begin{array}{c}2.987^{* * *} \\
(0.188)\end{array}$ & $\begin{array}{c}1.934^{* * *} \\
(0.323)\end{array}$ & $\begin{array}{l}1.761^{* * *} \\
(0.412)\end{array}$ \\
\hline yr_dum & Yes & Yes & Yes & Yes & Yes & Yes \\
\hline area_dum & Yes & Yes & Yes & Yes & Yes & Yes \\
\hline$N$ & 510 & 510 & 510 & 510 & 510 & 510 \\
\hline r2 & 0.605 & 0.613 & 0.625 & 0.631 & 0.640 & 0.642 \\
\hline
\end{tabular}

Note: Standard errors are in parentheses; ${ }^{* *} p<0.05$, and ${ }^{* * *} p<0.01$.

From the regression results in Table 2, it is found that by gradually adding control variables through the above regression, the core explanatory variable we are concerned about has been significantly suppressing the emission of pollution and reducing the impact on haze at the $1 \%$ level. That is to say, the greater the environmental protection tax charges, based on Pigou's tax and the Coase theorem, the more external costs will be internalized. This will, in turn, increase the marginal production cost of the company's products, and this overall effect will force companies to reduce pollutant emissions. From another perspective, the more an environmental protection tax is levied, the more that tax will encourage enterprises to update their environmental protection equipment and reduce pollutant emissions. This, in turn, will reduce the annual average concentration of haze. In general, the more environmental protection taxes are levied, the more restricting it is for enterprises to emit pollutants; this can have a significant effect on haze reduction. Specifically, for every $1 \%$ increase in environmental protection tax, the annual average PM2.5 concentration will be significantly reduced (by $7.0 \%$ ). This result is consistent with our principal analysis. 
In the regression table, with regard to the influence of the control variables on the haze, this study finds:

1. From the completion of the investment in the treatment of industrial waste gas in each province and city, the amount of investment in the treatment of industrial waste gas significantly suppresses the emission of haze at the level of $5 \%$. The greater the investment in the treatment of industrial waste gas, the more the emission of polluting haze is reduced. A negative correlation exists between the amount of investment in industrial waste gas and the emission of haze. Specifically, for every $1 \%$ increase in the amount of investment in industrial waste gas, the emission of haze will be reduced by $2.2 \%$. This shows that an increase in the amount of investment in treating industrial waste gas can effectively reduce the emission of haze. The investment also has a significant inhibitory effect in terms of reducing the emission of haze pollutants.

2. With regard to the effect of regional GDP on the emission of haze, there is a negative correlation; regional GDP also significantly inhibits the emission of haze at the level of $1 \%$. Specifically, for every $1 \%$ increase in regional GDP, the emission of haze will be significantly reduced (by $11.4 \%$ ). This finding means that the more developed a local economy is, the less will be the haze emitted in that locality. In reality, the more economically developed a place, the more the local government is concerned about the emission of haze. Some places have also suggested either moving some of the more polluting industrial enterprises away from economically developed areas, or upgrading the technical emissions equipment. Either option will reduce the emission of haze accordingly.

3. From the perspective of the degree of opening to the outside world and the proportion of the secondary industry structure effect on haze, both significantly contribute to the emission of haze at the $1 \%$ level. In addition, both have a positive relationship in terms of the emission of haze. The correlation means that, the higher the degree to which a province or city opens up to the outside world, the more foreign investment there will be. In these cases, the greater will be the increase in the emission of haze, and the emission of haze will have a negative scale effect. Moreover, the larger the proportion of secondary production structure of a province and city, the heavier the industry. In this case, the emission of haze will increase to a greater extent, because the emission of $\mathrm{SO}_{2}$ in haze mainly comes from the negative externally generated in the production process of secondary industry. In addition, the heavier the proportion of secondary industry, the more haze emissions that are generated. For every $1 \%$ increase in the degree of openness of a province or city to the outside world, the emissions of haze will increase by $5.1 \%$. For every $1 \%$ increase in the structural share of a province or city to the secondary industry, the emissions of haze will increase by $28.1 \%$.

4. With regard to the impact of population size on haze, population size is not significant in the model regression. This finding indicates that population size has no significant impact on haze emissions.

In summary, the above regression results also confirm our hypothesis that an increase in the environmental protection tax will reduce the annual concentration of PM2.5 in provinces and cities, showing a significant emission reduction effect. The principle of the environmental protection tax is "who pollutes is who taxes are levied upon". The collection of the environmental protection tax will increase the polluting enterprises' external costs. This, in turn, will encourage these enterprises to reduce the emissions of haze pollutants, or to upgrade their emission reduction equipment, thereby reducing the emission of haze.

\subsection{Robustness Test}

In order to verify the correctness of the above conclusions, and in view of the important core influencing factors, this article adopts the variable substitution method as a robustness analysis. This method is employed to conduct further tests on the above analysis.

In the existing research, there is another measure of haze; that is, sulfur dioxide emissions (represented by $\mathrm{SO}_{2}$ ), where the $\mathrm{SO}_{2}$ data for 30 provinces, from 2003-2019, were 
obtained from the "China Statistical Yearbook" and the "China Environmental Statistical Yearbook". Further data, from 2004 to 2020, were obtained from provincial statistical yearbooks. The robustness test of the effects of the environmental protection tax on haze (Table 3) shows that the results remain consistent with the regression results in Table 2. Specifically, the environmental protection tax significantly suppresses the emission of haze; the environmental protection tax also has a negative and significant impact on haze. The regression results were found to be consistent with the previous regression results in Table 2, after using the variable substitution methodology. This finding further confirms the robustness of the above correlation between environmental protection tax and haze.

Table 3. Robustness test of environmental protection tax on the haze emission reduction effect.

\begin{tabular}{|c|c|c|c|c|c|c|}
\hline $\mathrm{LnSo}_{2}$ & Model 1 & Model 2 & Model 3 & Model 4 & Model 5 & Model 6 \\
\hline $\operatorname{lnEptax}$ & $\begin{array}{c}-0.268 * * * \\
(0.056)\end{array}$ & $\begin{array}{c}-0.206^{* * *} \\
(0.054)\end{array}$ & $\begin{array}{c}-0.173^{* * *} \\
(0.038)\end{array}$ & $\begin{array}{c}-0.170 * * * \\
(0.038)\end{array}$ & $\begin{array}{c}-0.154^{* * *} \\
(0.030)\end{array}$ & $\begin{array}{c}-0.131^{* * *} \\
(0.0631\end{array}$ \\
\hline $\operatorname{lnIwg}$ & & $\begin{array}{c}-0.091^{* * *} \\
(0.015)\end{array}$ & $\begin{array}{c}-0.084^{* * *} \\
(0.026)\end{array}$ & $\begin{array}{c}-0.071^{* * *} \\
(0.016)\end{array}$ & $\begin{array}{c}-0.046^{* * *} \\
(0.004)\end{array}$ & $\begin{array}{c}-0.036^{* * *} \\
(0.008)\end{array}$ \\
\hline $\operatorname{lnGDP}$ & & & $\begin{array}{c}-0.761^{* * *} \\
(0.246)\end{array}$ & $\begin{array}{c}-0.696 \text { *** } \\
(0.188)\end{array}$ & $\begin{array}{c}-0.672 * * * \\
(0.175)\end{array}$ & $\begin{array}{c}-0.574^{* * *} \\
(0.061)\end{array}$ \\
\hline $\ln F d i$ & & & & $\begin{array}{l}0.103^{* *} \\
(0.042)\end{array}$ & $\begin{array}{l}0.064^{* *} \\
(0.013)\end{array}$ & $\begin{array}{l}0.023 \text { ** } \\
(0.010)\end{array}$ \\
\hline $\operatorname{lnIp}$ & & & & & $\begin{array}{c}2.724^{* * *} \\
(0.555)\end{array}$ & $\begin{array}{c}2.392 * * * \\
(0.332)\end{array}$ \\
\hline lnPeople & & & & & & $\begin{array}{c}0.068 \\
(0.196)\end{array}$ \\
\hline _cons & $\begin{array}{c}-3.154^{* * *} \\
(0.805)\end{array}$ & $\begin{array}{c}-3.231^{* * *} \\
(0.845)\end{array}$ & $\begin{array}{c}-2.535^{* * *} \\
(0.657)\end{array}$ & $\begin{array}{c}-2.593^{* * *} \\
(0.605)\end{array}$ & $\begin{array}{c}-10.5611^{* * *} \\
(1.402)\end{array}$ & $\begin{array}{c}-11.297^{* * *} \\
(0.866)\end{array}$ \\
\hline yr_dum & Yes & Yes & Yes & Yes & Yes & Yes \\
\hline area_dum & Yes & Yes & Yes & Yes & Yes & Yes \\
\hline $\bar{N}$ & 510 & 510 & 510 & 510 & 510 & 510 \\
\hline r2 & 0.542 & 0.575 & 0.595 & 0.596 & 0.647 & 0.767 \\
\hline
\end{tabular}

\section{Conclusions and Policy Recommendations}

The environmental protection tax studied in this paper was initially levied on 1 January 2018 in China. The environmental protection tax is based on the principle of "tax burden shift". The Chinese government changed the original pollution discharge fee directly into an environmental protection tax. Therefore, this paper uses the provincial panel data for the environmental protection tax, from 2003 to 2019, including the latest two years of data, to explore the effect of the environmental protection tax on haze. After theoretical and empirical analysis and testing, the study concludes the following: The environmental protection tax has a significant inhibitory effect on haze and can significantly reduce the emission of haze. The tax also has a significant effect on haze reduction. Moreover, a pollutant discharge fee system can also guide enterprises to reduce environmental pollution. The original intention of the environmental protection tax design was to use special funds for environmental governance. In this paper, after performing the robustness test using the variable substitution method, the environmental protection tax is still found to have a significant inhibitory effect on haze.

In response to the above research conclusions, this paper puts forward suggestions to optimize the emission reduction effect of the environmental protection tax on haze in China. First, the Chinese government should expand the scope of the environmental protection tax and gradually increase the tax rate. The current scope of the environmental protection tax mainly includes air pollutants, water pollutants, solid waste, and noise. According to the Organization for Economic Cooperation and Development (OECD) database, only a dozen countries and regions, including the United Kingdom, Japan, and the United States (in some regions), levy taxes on carbon dioxide emissions. China should consider including mobile sources of pollution into the scope of taxation, such as exhaust emissions from cars, ships, airplanes, etc. In addition, some items are not taxed as long as they do not exceed certain standards. The standards for these items should be gradually tightened, and the scope of 
taxation should be expanded. At the same time, the environmental protection tax can also gradually increase the tax rate, especially the tax rate of air pollution. If the haze caused by air pollution is very serious and has not been improved, the environmental protection tax can also adopt an excessive progressive tax rate. Second, the Chinese government should increase the supervision and collection of the environmental protection tax. The relevant law enforcement departments should increase environmental supervision and special rectification of outstanding environmental problems. The inspection of highly polluting enterprises should be increased and strengthened, and highly polluting and energy-consuming enterprises should be strictly supervised. Further, enterprises that do not comply with regulations should be publicly criticized, and measures such as tax incentives and tax breaks (for the environmental protection tax) should be used to motivate enterprises to perform industrial upgrading, reform, and innovation. Third, the Chinese government should strengthen the multi-sectoral linkage between regions, in order to improve haze management. Haze pollution in China has the characteristics of being spillover and regional in nature. Therefore, it is important to improve the mechanism of regional collaborative haze control. At the same time, it is important to improve the collection of information pertaining to environmental protection pollutants, and to enhance the communication and collaboration between taxation departments and environmental protection departments between regions. In addition, the waste of resources caused by poor communication and information sharing between departments must be reduced; a good and efficient working situation should be established between environmental protection departments and taxation departments. Finally, efforts should be made to protect and manage the ecological environment and to work together to build a green home and promote the sustainable development of China's economy and environment.

Author Contributions: Conceptualization, methodology, validation, quantitative analysis, investigation, writing - original draft preparation, X.L.; writing — review and editing, G.D. All authors have read and agreed to the published version of the manuscript.

Funding: This research was funded by the Philosophy and Social Science Planning Program of Shanghai, grant number 2020BJB003.

Institutional Review Board Statement: Not applicable.

Informed Consent Statement: Not applicable.

Data Availability Statement: Not applicable.

Conflicts of Interest: The authors declare no conflict of interest.

\section{References}

1. Zhao, S.; Xu, Y. Exploring the spatial variation characteristics and influencing factors of pm2.5 pollution in China: Evidence from 289 Chinese cities. Sustainability 2019, 11, 4751. [CrossRef]

2. Bovenberg, A.L.; Heijdra, B.J. Environmental tax policy and intergenerational distribution. J. Public Econ. 1998, 67, 1-24. [CrossRef]

3. Gao, P. Necessity, path and elements on the proposed of carbon tax in China. Tax. Res. 2011, 1, 50-54. (In Chinese)

4. Panayoutou, T. Demystifying the environmental kuznets curve: Turning a black box into a policy tool. Environ. Dev. Econ. 1997, 2, 465-484. [CrossRef]

5. Jia, K. Using fiscal and taxation policy and system construction to control haze. Environ. Prot. 2013, 41, 32-34. (In Chinese)

6. Wu, X.A. Environmental taxation is not a panacea for haze. Environ. Econ. 2013, 12, 64. (In Chinese)

7. Magat, W.A.; Viscusi, W.K. Effectiveness of the EPA's regulatory enforcement: The case of industry effluent standards. J. Law Econ. 1990, 33, 331-360. [CrossRef]

8. Laplante, B.; Rilstone, P. Environmental inspections and emissions of the pulp and paper industry in Quebec. J. Environ. Econ. Manag. 1996, 31, 19-36. [CrossRef]

9. Wang, H.; Wheeler, D. Financial incentives and endogenous enforcement in China's pollution levy system. J. Environ. Econ. Manag. 2005, 49, 174-196. [CrossRef]

10. Huo, Y.B. Study on the integration of air pollutant emissions trading in the Yangtze River delta. Ecol. Econ. 2012, 12, 181-184. (In Chinese)

11. Zhang, L.H.; Degejirifu; Liang, H.Y. Study on construction dust emission fee system levying in China. Environ. Eng. 2016, 34, 74-77. (In Chinese) 
12. Li, Y.Y.; Shen, K.R. Emission reduction effect of china 's pollution control policies: Based on empirical analysis of the interprovincial industrial pollution data. Manag. World 2008, 7, 7-17. (In Chinese)

13. Cui, Y.F.; Liu, X.C. Provincial tax competition and environmental pollution: Based on panel data from 1998 to 2006 in China. J. Financ. Econ. 2010, 36, 46-55. (In Chinese)

14. Zhang, Y. Study on the pollution-reducing effect of environmental tax and fees based on provincial panel data. J. Qingdao Univ. Sci. Technol. 2016, 32, 22-25. (In Chinese)

15. Yu, J.X.; Li, X. An empirical study on the effect of environmental protection tax on emission reduction in China. Tax. Res. 2018, 23, 69-75. (In Chinese)

16. Li, H.; Xiong, Z.X. The impact of ecological deficit tax and income tax cuts on economic growth: A CGE analysis in China. Econ. Res. J. 2017, 52, 124-138. (In Chinese)

17. Luo, H.Y.; Qu, X.E.; Hu, Y.X. The impact of government regulation on enterprises' emission reduction behavior under environmental protection tax system-analysis based on evolutionary game. J. Beijing Inst. Technol. 2020, 22, 1-12. (In Chinese)

18. Pászto, V.; Zimmermannová, J.; Skaličková, J.; Sági, J. Spatial patterns in fiscal impacts of environmental taxation in the EU. Economies 2020, 8, 104. [CrossRef]

19. López Pérez, S.d.J.; Vence, X. When harmful tax expenditure prevails over environmental tax: An assessment on the 2014 Mexican fiscal reform. Sustainability 2021, 13, 11269. [CrossRef]

20. Hu, B.; Dong, H.J.; Jiang, P.; Zhu, J.A. Analysis of the applicable rate of environmental tax through different tax rate scenarios in China. Sustainability 2020, 12, 4233. [CrossRef]

21. Chien, F.; Sadiq, M.; Nawaz, M.A.; Hussain, M.S.; Tran, T.C.; Thanh, T.L. A step toward reducing air pollution in top Asian economies: The role of green energy, eco-innovation, and environmental taxes. J. Environ. Manag. 2021, 297, 113420. [CrossRef] [PubMed]

22. Pigou, A.C. The Economics of Welfare, 4th ed.; Macmillan: London, UK, 1932.

23. DeSerpa, A.C. Pigou and coase: A mathematical reconciliation. J.Public Econ. 1994, 54, 267-286. [CrossRef]

24. Deryugina, T.; Moore, F.; Tol, R.S.J. Environmental applications of the Coase Theorem. Environ. Sci. Policy 2021, 120, 81-88. [CrossRef] 